\title{
Bleomycin-Induced Fatal Lung Toxicity
Misdiagnosed as Covid-19 Pneumonia: A Case Report
}

\section{Covid 19 Pnömonisi ile Karışan Bleomisine Bağlı Fatal Akciğer Toksisitesi: Olgu Sunumu}

Murathan Köksal', Yasin Celal Güneş²

\section{Abstract}

Bleomycin is a chemotherapeutic agent that is preferred for the treatment of testicular cancer, lymphoma and some squamous cell carcinomas. Bleomycininduced lung toxicity is a common, but rarely fatal side-effect, and the radiological image of which can be confused with other reasons which makes organizing pneumonia pattern. We report here on the case of a 40-year-old male patient with testicular cancer with bleomycin-induced fatal lung toxicity that was misdiagnosed as Covid-19 pneumonia. The patient suffered subsequent fatal spontaneous pneumomediastinum, pneumothorax, and pulmonary interstitial and subcutaneous emphysema, and died from respiratory failure.

Key words: Bleomycin, lung toxicity, covid-19, organizing pneumonia.

\section{Özet}

Bleomisin testis kanseri, lenfoma ve bazı skuamöz hücreli kanserlerin tedavisinde tercih edilen kemoterapotik bir ajandır. Bleomisine bağlı akciğer toksisitesi sık karşılaşılmakla birlikte nadiren fatal yan etkiye neden olmaktadır. Ayrıca bleomisine bağlı akciğer hasarının radyolojik görüntüleri diğer organize pnömoni paterni yapan nedenler karışabilmektedir. Bu olgu sunumunda bilinen testis kanseri tanısı olan 40 yaşında erkek hastanın, Covid 19 pnömonisi ile karışan bleomisin bağlı fatal akciğer hasarı sunulmaktadır. Hasta bu zeminde spontan fatal pnömotoraks, pnömomediasten ve pulmoner intersisyal ve subkütan amfizem gelişimi nedeniyle respiratuar arrest kaynaklı kaybedilmiştir.

Anahtar Sözcükler: Bleomisin, akciğer toksisitesi, covid-19, organize pnömoni.
'Ministry of Health Ankara City Hospital, Ankara, Turkey ${ }^{2}$ SBU Ankara Kecioren SUAM, Ankara, Turkey
'Sağlık Bakanlığı Ankara Şehir Hastanesi, Ankara ${ }^{2}$ SBÜ Ankara Keçiören SUAM, Ankara

Submitted (Başvuru tarihi): 08.08.2020 Accepted (Kabul tarihi): 03.1 1.2020

Correspondence (iletişim): Murathan Köksal, Ministry of Health Ankara City Hospital, Ankara, Turkey

e-mail: murathankoksal@gmail.com 
Bleomycin is a chemotherapeutic agent that has been isolated from Streptomyces verticillus, and that has been used successfully for the treatment of testicular cancer, lymphoma and squamous cell carcinomas. The main limitations of bleomycin therapy are dose-dependent lung toxicity and fibrosis. It can rarely cause fatal lung toxicity. Accordingly, early diagnosis and treatment, and the prevention of limiting toxicities such as bleomycin-induced lung injury, are important.

\section{CASE}

A 40-year-old male patient with a history of diabetes and testicular cancer was admitted to the emergency department of our hospital with dyspnea. A physical examination revealed blood pressure of $120 / 63 \mathrm{mmHg}$, oxygen saturation of $83 \%$, body temperature of $36.8^{\circ} \mathrm{C}$ and a $\mathrm{C}$ reactive protein level of $0.022 \mathrm{~g} / \mathrm{L}(\mathrm{N}: 0.005 \mathrm{~g} / \mathrm{L})$. Other blood test results were normal. Following a physical examination, the patient was referred to the Radiology Department for an anteroposterior chest radiograph. A chest $X$-ray showed increased reticular opacities in the upper and lower zones, left lung multifocal scattered opacities in the perihilar region. A subsequent chest computed tomography (CT) revealed an organized stage of Coronavirus Disease 2019 (COVID-19) pneumonia with diffuse fibrotic changes (Figure 1 and 2). Based on the results, the patient was hospitalized in the infectious disease inpatient clinic. Hydroxychloroquine, azithromycin ceftriaxone were started. In the first week of hospitalization, the polymerase chain reaction (PCR) test result for COVID-19 was twice negative, and the respiratory pathogen test result and sputum culture were also negative. The patient was not evaluated by bronchoscopy. When serologic test results came up negative, the patient was re-evaluated based on medical history, which revealed that he had undergone three cycles of an etoposide-bleomycincisplatin chemotherapy protocol, and had actually experienced shortness of breath for two months, since the last dose. Following this re-evaluation, the patient was diagnosed with bleomycin-induced pneumonitis. Other medications were stopped, and steroid treatment was started. On the eighth day of hospitalization, the patient's partial pressure of oxygen $\left(\mathrm{PaO}_{2}\right)$ levels decreased suddenly and he was referred to the Radiology department for a further anteroposterior chest radiograph and chest $C T$, which revealed bleomycin-induced diffuse fibrosis, pulmonary interstitial pneumonia and spontaneous pneumomediastinum, pneumothorax and pulmonary interstitial emphysema (Figure 3 and 4). The patient was transferred to the intensive care unit and a chest tube was inserted. Despite the treatment protocol, the patient died from respiratory failure after a few hours.

\section{DISCUSSION}

Bleomycin, the most significant side effect of which is lung toxicity, is a chemotherapeutic agent that is preferred for the treatment of testicular cancer, lymphoma and some squamous cell carcinomas. Due to Bleomycin-induced lung toxicity (BILT), an endothelial and interstitial capillary edema, and an increase in surfactant overproduction and fibroblasts production were observed as a result of the mediators released by macrophages. These findings were consistent with the histological findings of diffuse alveolar damage, interstitial pneumonia and interstitial pulmonary fibrosis (1-3).

BILT presents with such clinical manifestations as fever, dyspnea, pleurisy and substernal pain. Patient older than 70, cumulative doses higher than $450 \mathrm{mg}$, renal insufficiency, administration path, oxygen treatment, smoking, granulocyte colony-stimulating factor (G-CSF) administration and bleomycin hydrolase activity are some of the predisposing factors (4-8).

A BILT diagnosis is based on exclusion, and is often excluded through microbiological and laboratory testing such as culture, gram staining of sputum and PCR. Pneumocystis jiroveci pneumonia (PJP) in particular should always be investigated (9).

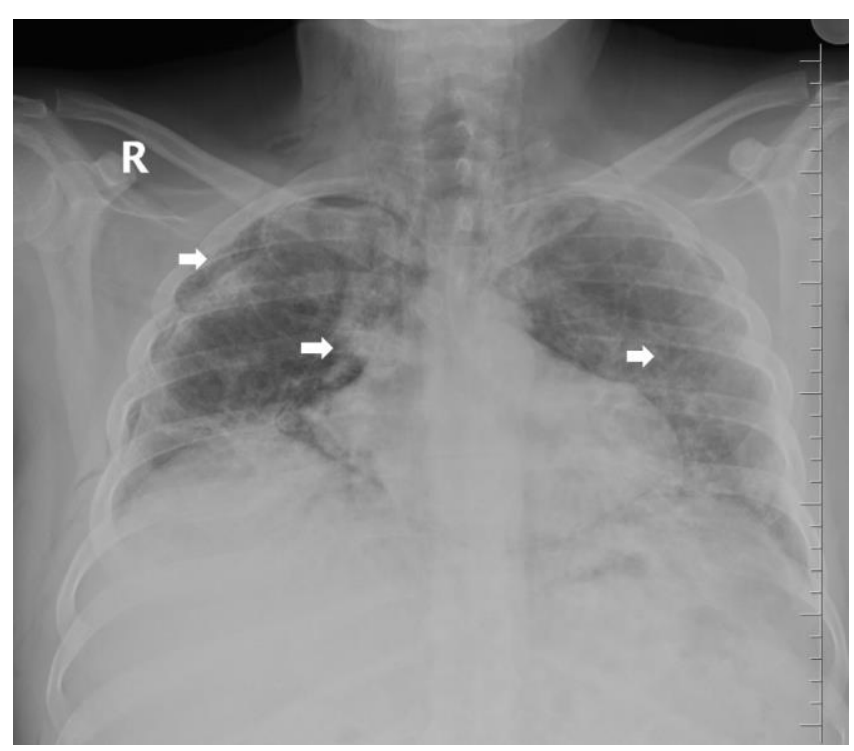

Figure 1: Chest X-Ray showing volume loss in the right lung, increased reticular opacities in the upper and lower zones, left lung multifocal scattered opacities in the perihilar region (arrows) 


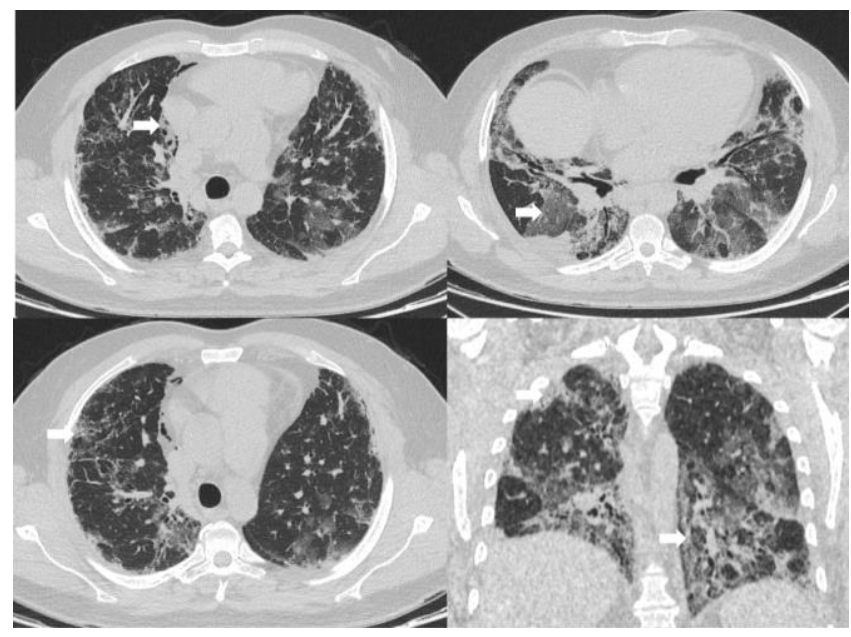

Figure 2: Chest CT scan revealing bleomycin induced lung toxicity, diffuse lung fibrosis, multifocal ground glass opacities with peribronchial cuffing, and cylindrical bronchiectasis (arrows). This CT scan showed no pneumothorax or pneumomediastinum

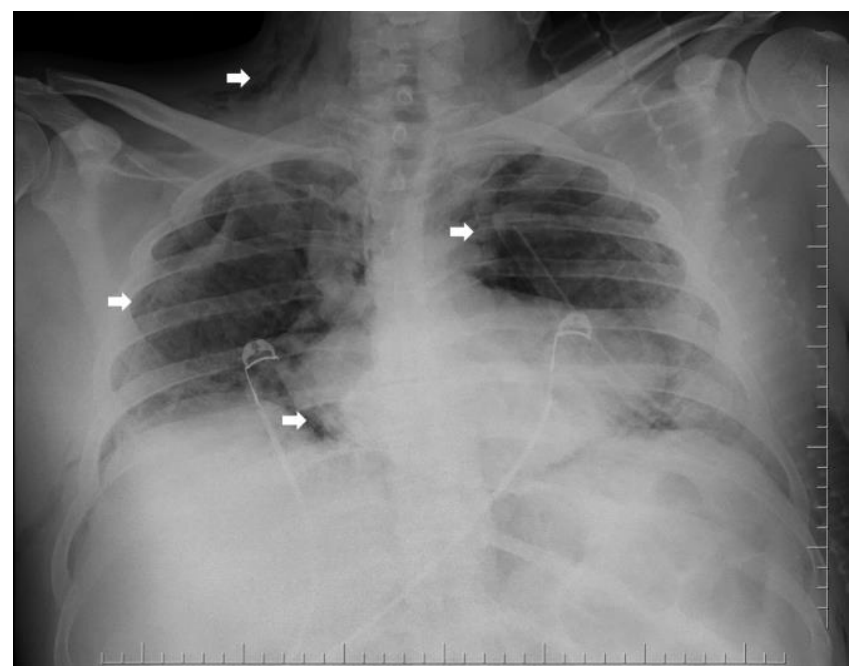

Figure 3: Chest X-Ray showing bilateral pneumothorax and pneumomediastinum. Cardiac contours are clearly identified by pneumomediastinum. Subcutaneous emphysema seen in the right neck region

Bleomycin lung toxicity is well established, and can be detected as bleomycin-induced pneumonitis (10). In chest high resolution computed tomography (HRCT) it can appear as diffuse alveolar damage, pulmonary fibrosis, organizing pneumonia pattern (OP) or nonspecific interstitial pneumonia pattern (NSIP). The HRCT features that imply underlying pulmonary fibrosis are a honeycomb pattern, traction bronchiectasis and reticulation. Diffuse alveolar damage is associated with ground-glass opacities and consolidations. The $\mathrm{OP}$ pattern manifests as bilateral multifocal ground glass opacifications and/or consolidations with peribronchial or subpleural distribution (9). CT findings of COVID-19 have enabled the diagnosis of the most common pattern-resembled OP (11).

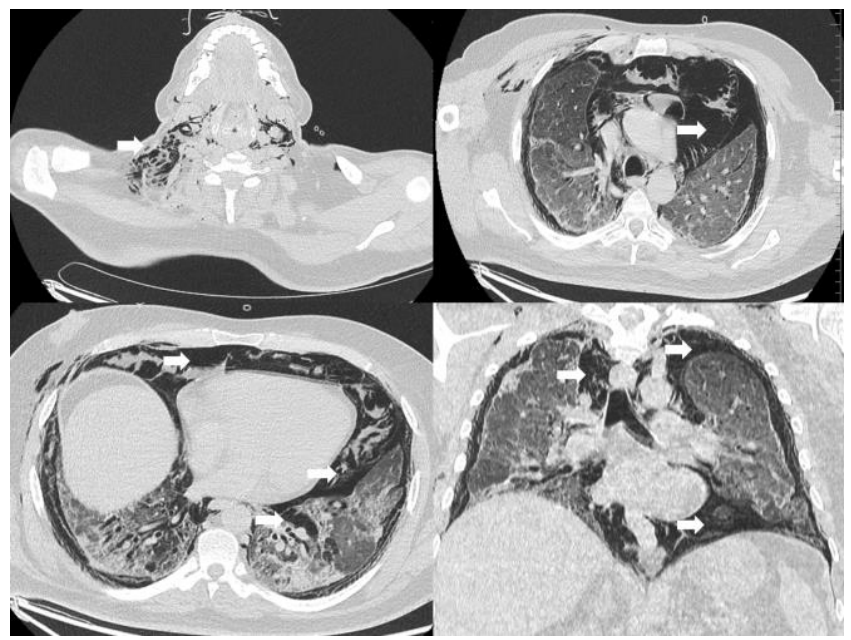

Figure 4: Chest CT scan showing extensive subcutaneus empyhsma in the neck, bilateral extensive pneumothorax and pneumomediastinum. Bilateral pulmonary emphysema seen in the lower lobes (arrows)

COVID-19 typically presents with ground glass opacities with or without consolidation, with a peripheral, posterior, and diffuse or lower lung zone distribution. Crazy paving pattern, reverse halo sign and other findings of OP patterns seen later in the disease are also typical signs (12). Primary or secondary organizing pneumonia, such as drug toxicity, connective tissue disease, some viral pneumonias and acute lung injury patterns are the main differential diagnoses of COVID-19 pneumonia.

The mortality rate associated with BILT is $1-2 \%$ (13). Spontaneous pneumomediastinum, pneumothorax and pulmonary interstitial emphysema are very rare fatal complications of the treatment, as identified in our case study, as well as in a few studies in literature (14-17).

\section{CONCLUSION}

The radiology of BILT can be confusing, and so patients may be misdiagnosed as COVID-19. During the ongoing pandemic, the history and follow-up of the patient, as well as the radiological images, must serve for correct diagnoses, as in our case.

\section{CONFLICTS OF INTEREST}

None declared.

\section{AUTHOR CONTRIBUTIONS}

Concept - M.K., Y.C.G.; Planning and Design - M.K., Y.C.G.; Supervision - M.K., Y.C.G.; Funding -; Materials -; Data Collection and/or Processing -; Analysis and/or Interpretation -; Literature Review - Y.C.G.; Writing - M.K., Y.C.G.; Critical Review - M.K. 


\section{YAZAR KATKILARI}

Fikir - M.K., Y.C.G.; Tasarım ve Dizayn - M.K., Y.C.G.; Denetleme - M.K., Y.C.G.; Kaynaklar -; Malzemeler -; Veri Toplama ve/veya İşleme -; Analiz ve/veya Yorum -; Literatür Taraması - Y.C.G.; Yazıyı Yazan - M.K., Y.C.G.; Eleştirel İnceleme - M.K.

\section{REFERENCES}

1. Copper JA Jr. Drug-induced lung disease. Adv Intern Med 1997; 42:231-68.

2. Weiss RB, Muggia FM. Cytotoxic drug-induced pulmonary disease: update 1980. Am J Med 1980; 68:259-66. [CrossRef]

3. Bedrossian CW, Luna MA, Mackay B, Lichtiger B. Ultrastructure of pulmonary bleomycin toxicity. Cancer 1973; 32:44-51. [CrossRef]

4. Sleijfer S. Bleomycin-induced pneumonitis. Chest 2001; 120:617-24. [CrossRef]

5. Comis RL. Bleomycin pulmonary toxicity: current status and future directions. Semin Oncol 1992; 19(Suppl 5):64-70.

6. Hay J, Shahzeidi S, Laurent G. Mechanisms of bleomycin-induced lung damage. Arch Toxicol 1991; 65:81-94. [CrossRef]

7. Rabinowits M, Souhami L, Gil RA, Andrade CA, Paiva HC. Increased pulmonary toxicity with bleomycin and cisplatin chemotherapy combinations. Am J Clin Oncol 1990; 13:132-8. [CrossRef]

8. Jóna Á, Miltényi Z, Póliska S, Bálint BL, Illés Á. Effect of Bleomycin hydrolase gene polymorphism on late pulmonary complications of treatment for Hodgkin lymphoma. PLoS One 2016; $11:$ e0157651. [CrossRef]

9. Reinert T, Baldotto CSR, Nunes FAP, Scheliga AAS. Bleomycin-induced lung injury.J Cancer Res 2013;2013. [CrossRef]

10. Rossi SE, Erasmus JJ, McAdams HP, Sporn TA, Goodman PC. Pulmonary drug toxicity: radiologic and pathologic manifestations. Radiographics 2000; 20:1245-59. [CrossRef]

11. Wu $Y, X_{i e} Y L$, Wang $X$. Longitudinal $C T$ findings in COVID-19 pneumonia: case presenting organizing pneumonia pattern. Radiol Cardiothorac Imaging 2020;2:e200031. [CrossRef]

12. Froudarakis $M$, Hatzimichael $E$, Kyriazopoulou L, Lagos $K$ Pappas $P$, Tzakos AG, et al. Revisiting bleomycin from pathophysiology to safe clinical use. Crit Rev Oncol Hematol 2013; 87:90-100. [CrossRef]

13. Simpson S, Kay FU, Abbara S, Bhalla S, Chung JH, Chung $M$, et al. Radiological Society of North America Expert Consensus Statement on Reporting Chest CT Findings Related to COVID-19. Endorsed by the Society of Thoracic Radiology, the American College of Radiology, and RSNA. J Thorac Imaging 2020; 35:219-227. [CrossRef]

14. Araujo MS, Fernandes FL, Kay FU, Carvalho CR. Pneumomediastinum, subcutaneous emphysema, and pneumothorax after a pulmonary function testing in a patient with bleomycin-induced interstitial pneumonitis. J Bras Pneumol 2013; 39:613-9. [CrossRef]

15. Frusch N, Servais S, De Prijck B, Corhay JL, Beguin Y, Louis $R$, et al. Spontaneous pneumomediastinum caused by bleomycin-induced pneumonitis. Acta Clin Belg 2012; 67:370-1. [CrossRef]

16. Barras M, Uhlmann M. Spontaneous pneumomediastinum and bilateral pneumothoraces in a patient with Bleomycin-induced pneumonitis. Eur J Case Rep Intern Med 2017; 4:000727. [CrossRef]

17. Martínez-Granados RJ, Reyes-Mondragón AL, ZayasVillanueva OA, Vidal-Gutiérrez O, Salazar-Mejía CE. Bleomycin-induced pneumomediastinum in a young man with testicular cancer. Med Clin Prac 2020; 3:100114. [CrossRef] 